\title{
RHOA mutation may be associated with diffuse-type gastric cancer progression, but is it gain or loss?
}

\author{
Masahiro Maeda $^{1,2} \cdot$ Toshikazu Ushijima $^{1}$
}

Received: 25 June 2015 / Accepted: 22 July 2015/Published online: 22 August 2015

(C) The International Gastric Cancer Association and The Japanese Gastric Cancer Association 2015

\begin{abstract}
Abbreviations
DGC Diffuse-type gastric cancer

RHOA Ras homolog gene family member A

RHOA-wt RHOA wild type

TCGA The Cancer Genome Atlas
\end{abstract}

RHOA, Ras homolog gene family member A, encoding a small GTPase, is a novel and contentious cancer driver gene. In 2014, frequent somatic RHOA mutation was identified almost exclusively in diffuse-type gastric cancer (DGC) in three studies [1-3]. Kakiuchi et al. [1] and The Cancer Genome Atlas (TCGA) Research Network [2] indicated gain-of-function mutations of RHOA. On the other hand, Wang et al. [3] indicated loss-of-function mutations of RHOA. This potential discrepancy attracted great attention from many investigators, including those who enthusiastically focus on RHOA as a potential therapeutic target. Historically, although increased RHOA expression was frequently observed in various cancers and was suggested to be associated with disease progression

This comment refers to the article available at doi:10.1007/s10120015-0493-0.

Toshikazu Ushijima

tushijim@ncc.go.jp

Masahiro Maeda

mamaeda@ncc.go.jp

1 Division of Epigenomics, National Cancer Center Research Institute, Tsukiji, Chuo-ku, Tokyo 104-0045, Japan

2 Department of Gastrointestinal Surgery, Kyoto University Graduate School of Medicine, Yoshida-Konoe-cho, Sakyoku, Kyoto 606-8501, Japan and poor prognosis, RHOA mutation was uncommon [4]. In this issue of Gastric Cancer, Ushiku et al. [5] report clinicopathological characteristics of RHOA-mutated DGCs for the first time [5].

Ushiku et al. analyzed 87 DGCs, 22 RHOA-mutated DGCs and 65 RHOA wild-type (RHOA-wt) DGCs, for their histopathological and clinical characteristics, especially focusing on heterogeneity of histological features and growth patterns of DGCs. RHOA-mutated DGCs more frequently contained focal tubular differentiation in their intramucosal areas than RHOA-wt DGCs. Notably, RHOAmutated DGCs were significantly inclined to spread laterally in the mucosae with infiltration between normal gastric glands without well-circumscribed margins (permeative growth), resulting in a lower ratio of deeply invasive components to mucosal components in RHOA-mutated DGCs than in RHOA-wt DGCs. In previous studies [1, 3], RHOA mutations were detected both in intramucosal regions and in invasive regions and also both in diffuse components and in tubular components, and were considered to occur in the early phase of carcinogenesis. From these findings taken together, it was suggested that intestinal-type intramucosal gastric cancer possibly develops into DGC through stepwise progression in the presence of a $R H O A$ mutation.

Ushiku et al. also investigated the clinical impact of RHOA mutation on patient survival, but they did not observe significant differences. However, they discuss the possibility that RHOA deregulation could be still significantly associated with patient survival for the following reasons. First, this study consisted of a small cohort; therefore, a larger cohort would be required to determine the prognostic significance of RHOA mutation. Second, the heterogeneity in the cohort might have influenced the result of the analysis. The cohort included five patients with 
linitis plastica type cancer (so-called scirrhous cancer), none of whom had an RHOA mutation. Linitis plastica, a subtype of DGC with extremely poor prognosis, might have resulted in worse prognosis of the patients without RHOA mutation. Third, deregulation of RHOA signaling may be caused by genomic abnormalities other than RHOA mutation. Indeed, CLDN18-ARHGAP fusion was recently identified in the genomically stable subgroup corresponding to DGC in terms of histological features. CLDN18ARHGAP fusion was mutually exclusive with $R H O A$ mutation and could affect the activation of RHOA-related signaling pathways [2].

Despite these novel findings, the major question of whether the RHOA mutation is a gain-of-function or a loss-of-function mutation still remains unsolved. The three initial studies conducted whole-exon and/or whole-genome sequencing, and reported that frequent $R H O A$ mutation was observed almost exclusively in DGC or the genomically stable subgroup
(14.3-25.3\%, Table 1) [1-3]. Most RHOA mutations were unevenly distributed in the amino-terminal domain and weakly clustered in two adjacent functional domains involved in GTP binding and interaction with RHOA effectors. The most frequent mutations were R5Q and Y42C, followed by G17E, in Kakiuchi et al. [1]; Y42C followed by L57V in Wang et al. [3]; and Y42C followed by Y42S in TCGA [2]. These sites and regions were referred to as hotspots and hotspot regions (HS1/2) [1-3]. Kakiuchi et al. stated that mutational hotspot residues in their study (R5, Y42, and G17) were highly conserved among Rho family proteins. The presence of such hotspot regions suggests a gain-of-function mutation. At the same time, RHOA mutations often conformed to the classic two-hit suppressor gene model, being associated with concurrent loss of heterozygosity, which suggested a loss-offunction mutation [3].

Biological analysis revealed multiple aspects of $\mathrm{RHOA}$ mutations. Wang et al. [3] found that RHOA mutants

Table 1 The comparison of three studies on RHOA mutation

\begin{tabular}{|c|c|c|c|c|c|c|c|}
\hline Authors & $\begin{array}{l}\text { Subjects and } \\
\text { classification) }\end{array}$ & Method & $\begin{array}{l}\text { Frequency of } \\
\text { RHOA mutation }\end{array}$ & Mutation sites ${ }^{\mathrm{a}}$ & $\begin{array}{l}\text { Additional } \\
\text { findings }\end{array}$ & $\begin{array}{l}\text { Effect of mutants, } \\
\text { and type of } \\
\text { cell/analysis }\end{array}$ & $\begin{array}{l}\text { Suggested } \\
\text { mutation } \\
\text { type }\end{array}$ \\
\hline $\begin{array}{l}\text { Kakiuchi } \\
\text { et al. [1] }\end{array}$ & $\begin{array}{l}\text { Diffuse-type gastric } \\
\text { cancer, } 30 \text { cases for } \\
\text { exploration and } 57 \\
\text { cases for validation; } \\
\text { intestinal-type gastric } \\
\text { cancer, } 51 \text { cases } \\
\text { (Lauren classification) }\end{array}$ & WES & $\begin{array}{l}\text { Diffuse type, } \\
25.3 \%(22 / \\
87) ; \text { intestinal } \\
\text { type, } 0 \%(0 / \\
51)\end{array}$ & $\begin{array}{l}\text { Hotspot, R5W (5), } \\
\text { G17E (3), Y42C (6); } \\
\text { others, R5Q (1), L22R } \\
\text { (1), V38G (1), E54K } \\
\text { (1), W58S (1), R68P } \\
\text { (1), L69R (2), Y74D } \\
\text { (1) }\end{array}$ & & $\begin{array}{l}\text { Growth-promoting } \\
\text { effect (SW948 } \\
\text { cell line) }\end{array}$ & $\begin{array}{l}\text { Gain of } \\
\text { function }\end{array}$ \\
\hline $\begin{array}{l}\text { Wang et al. } \\
{[3]}\end{array}$ & $\begin{array}{l}\text { Gastric cancer, } 100 \\
\text { cases for exploration } \\
\text { and } 183 \text { cases for } \\
\text { validation (WHO } \\
\text { classification) }\end{array}$ & WGS & $\begin{array}{l}\text { Diffuse type, } \\
14.3 \%(14 / \\
98) ; \text { mixed/ } \\
\text { indeterminate } \\
\text { type, } 7.8 \%(4 / \\
51) ; \text { intestinal } \\
\text { type, } 0 \%(0 / \\
134)\end{array}$ & $\begin{array}{l}\text { Hotspot, Y42C (8), } \\
\text { L57V (4); others, } \\
\text { R5W (2), G17E (2), } \\
\text { L22R (1), Y34C (1), } \\
\text { F39V (1), E40V (1), } \\
\text { D59G (1), A61D (1), } \\
\text { G62E (1), L81fs b }\end{array}$ & $\begin{array}{l}\text { Concurrent } \\
\text { LOH } \\
\text { (L57V, } \\
\text { Y42C, } \\
\text { E40V, } \\
\text { D59G), } \\
\text { two-hit } \\
\text { mutations }\end{array}$ & $\begin{array}{l}\text { (1) Impairment of } \\
\text { GTP binding } \\
\text { capacity (293T/ } \\
17 \text { cells), (2) } \\
\text { escape from } \\
\text { anoikis (mouse } \\
\text { intestinal } \\
\text { organoids) }\end{array}$ & $\begin{array}{l}\text { Loss of } \\
\text { function }\end{array}$ \\
\hline $\begin{array}{l}\text { TCGA } \\
\text { Research } \\
\text { Network } \\
{[2]}\end{array}$ & $\begin{array}{l}\text { Gastric cancer, } 295 \\
\text { cases }\end{array}$ & $\begin{array}{l}\text { WES/ } \\
\text { WGS }\end{array}$ & $\begin{array}{l}\text { Whole cohort, } \\
5.4 \%(16 / \\
295) ; \mathrm{GS}, \\
15 \%(9 / 58)\end{array}$ & $\begin{array}{l}\text { Hotspot region HS1 } \\
\text { (effector region), } \\
\text { Y42C (3), Y42S (2), } \\
\text { Y34C (1), F39C (1), } \\
\text { E40K (1), N41K (1); } \\
\text { hotspot region HS2 (G } \\
\text { box binding region). } \\
\text { L57V (1), D59Y (1), } \\
\text { T60K (1), A61D (1), } \\
\text { G62R (1), G62E (1); } \\
\text { others, R5W (1), } \\
\text { G17E (1) }\end{array}$ & $\begin{array}{l}\text { CLDN18- } \\
\text { ARHGAP } \\
\text { fusion } \\
\text { (mutually } \\
\text { exclusive } \\
\text { with } \\
\text { RHOA } \\
\text { mutation) }\end{array}$ & $\begin{array}{l}\text { Activation of } \\
\text { RhoA-ROCK } \\
\text { pathway } \\
\text { (bioinformatic } \\
\text { analysis through } \\
\text { evaluation of } \\
\text { gene expression } \\
\text { status) }\end{array}$ & $\begin{array}{l}\text { Gain of } \\
\text { function }\end{array}$ \\
\hline
\end{tabular}

In the study by The Cancer Genome Atlas (TCGA) Research Network, gastric cancers were divided into four groups on the basis of the comprehensive molecular approach. Diffuse-type gastric cancer was enriched in the genomically stable (GS) subtype (40/55).

LOH loss of heterozygosity, ROCK Rho-associated protein kinase, WES whole-exon sequencing, WGS whole-genome sequencing

a The number of mutations is given in parentheses.

${ }^{\mathrm{b}} f_{s}$ indicates a truncating alteration. 
(Y42C, L57V) promoted escape from anoikis in mouse intestinal organoid cultures, which might be involved in the diffuse morphological phenotype. Kakiuchi et al. [1] demonstrated a growth-promoting effect of RHOA mutants (G17E, Y42C) in an RHOA-mutant cell line (SW948). The fact that RHOA mutants could show oncogenic phenotypes in the presence of a wild-type allele suggested a gain-offunction effect of RHOA mutation. Additionally, bioinformatic analysis predicted activation of the RhoA-Rho-associated protein kinase signaling pathway through evaluation of gene expression status in the pathways putatively regulated by $R H O A$ [2]. In contrast, biochemical analysis showed that RHOA mutants $(\mathrm{Y} 42 \mathrm{C}, \mathrm{L} 57 \mathrm{~V})$ had a significantly reduced amount of the GTP-bound active form compared with RHOA-wt in 293T/17 cells (a derivative of 293T cells which are isolated from human embryonic kidneys). The defective RHOA activity showed a loss-of-function effect of the RHOA mutations [3].

These data showed the hotspot RHOA mutants had characteristics of both "biochemical loss of function" and "biological gain of function." Namely, the hotspot RHOA mutants not only lost their GTP-binding capacity but also acquired an oncogenic activity, possibly in an unidentified signaling pathway. A remarkable example of such an acquisition of oncogenic activity unrelated to intrinsic physiological activity is known for $I D H I$ and $I D H 2$ genes, which are recurrently mutated in glioma $[6,7]$ and acute myeloid leukemias[8]. IDH1/IHD2 mutants acquire a neomorphic enzymatic ability to convert $\alpha$-ketoglutarate into 2-hydroxyglutarate [9], which is unrelated to its physiological activity to mediate the reversible conversion between isocitrate and $\alpha$-ketoglutarate and causes suppression of epigenetic enzymes, TET enzymes, resulting in aberrant epigenetic and gene expression profiles [10]. Neomorphic activity of RHOA mutants may well explain the biochemical loss of function and biological gain of function. The clinicopathological behaviors of DGCs with RHOA mutation reported here may lead to a clue.

\section{References}

1. Kakiuchi M, Nishizawa T, Ueda H, Gotoh K, Tanaka A, Hayashi $\mathrm{A}$, et al. Recurrent gain-of-function mutations of RHOA in diffuse-type gastric carcinoma. Nat Genet. 2014;46(6):583-7.

2. The Cancer Genome Atlas Research Network. Comprehensive molecular characterization of gastric adenocarcinoma. Nature. 2014;513(7517):202-9.

3. Wang K, Yuen ST, Xu J, Lee SP, Yan HH, Shi ST, et al. Wholegenome sequencing and comprehensive molecular profiling identify new driver mutations in gastric cancer. Nat Genet. 2014;46(6):573-82.

4. Karlsson R, Pedersen ED, Wang Z, Brakebusch C. Rho GTPase function in tumorigenesis. Biochim Biophys Acta. 2009;1796(2):91-8.

5. Ushiku T, Ishikawa $\mathrm{S}$, Kakiuchi $\mathrm{M}$, Tanaka A, Katoh $\mathrm{H}$, Aburatani $\mathrm{H}$, et al. RHOA mutation in diffuse-type gastric cancer: a comparative clinicopathology analysis of 87 cases. Gastric Cancer. 2015. 10.1007/s10120-015-0493-0.

6. Parsons DW, Jones S, Zhang X, Lin JC, Leary RJ, Angenendt P, et al. An integrated genomic analysis of human glioblastoma multiforme. Science. 2008;321(5897):1807-12.

7. Yan H, Parsons DW, Jin G, McLendon R, Rasheed BA, Yuan W, et al. IDH1 and IDH2 mutations in gliomas. N Engl $\mathrm{J}$ Med. 2009;360(8):765-73.

8. Figueroa ME, Abdel-Wahab O, Lu C, Ward PS, Patel J, Shih A, et al. Leukemic IDH1 and IDH2 mutations result in a hypermethylation phenotype, disrupt TET2 function, and impair hematopoietic differentiation. Cancer Cell. 2010;18(6):553-67.

9. Dang L, White DW, Gross S, Bennett BD, Bittinger MA, Driggers EM, et al. Cancer-associated IDH1 mutations produce 2-hydroxyglutarate. Nature. 2009;462(7274):739-44.

10. Prensner JR, Chinnaiyan AM. Metabolism unhinged: IDH mutations in cancer. Nat Med. 2011;17(3):291-3. 